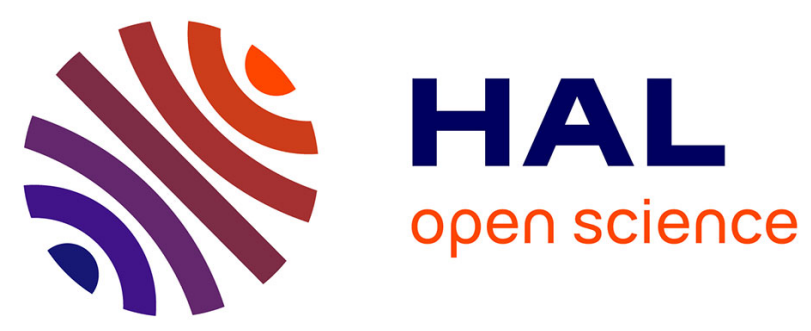

\title{
The Impact of Large Erosional Events and Transient Normal Stress Changes on the Seismicity of Faults
}

\author{
Louise Jeandet Ribes, N. Cubas, H. S Bhat, Philippe Steer
}

\section{To cite this version:}

Louise Jeandet Ribes, N. Cubas, H. S Bhat, Philippe Steer. The Impact of Large Erosional Events and Transient Normal Stress Changes on the Seismicity of Faults. Geophysical Research Letters, 2020, 47 (22), pp.e2020GL087631. 10.1029/2020GL087631 . insu-03011622v2

\section{HAL Id: insu-03011622}

\section{https://hal-insu.archives-ouvertes.fr/insu-03011622v2}

Submitted on 25 Nov 2020

HAL is a multi-disciplinary open access archive for the deposit and dissemination of scientific research documents, whether they are published or not. The documents may come from teaching and research institutions in France or abroad, or from public or private research centers.
L'archive ouverte pluridisciplinaire HAL, est destinée au dépôt et à la diffusion de documents scientifiques de niveau recherche, publiés ou non, émanant des établissements d'enseignement et de recherche français ou étrangers, des laboratoires publics ou privés. 


\section{Geophysical Research Letters}

\author{
RESEARCH LETTER \\ 10.1029/2020GL087631 \\ Key Points: \\ - We investigate seismicity response \\ to an erosional event by modeling \\ the effects of transient normal stress \\ changes on a frictional fault \\ - Erosional events with a duration \\ shorter than a seismic cycle can \\ increase the seismicity rate and the \\ proportion of small earthquakes \\ - Large erosional events have the \\ potential to contribute significantly \\ to the deformation of the first \\ kilometers of the Earth's crust
}

Supporting Information:

- Supporting Information S1

Correspondence to:

L. Jeandet Ribes,

louise.jeandet@sorbonne-universite.fr

Citation:

Jeandet Ribes, L., Cubas, N., Bhat, H. S. \& Steer, P. (2020). The impact of large erosional events and transient normal stress changes on the seismicity of faults. Geophysical Research Letters, 47, e2020GL087631. https://doi.org/ 10.1029/2020GL087631

Received 21 FEB 2020

Accepted 4 NOV 2020

Accepted article online 9 NOV 2020

\section{The Impact of Large Erosional Events and Transient Normal Stress Changes on the Seismicity of Faults}

\author{
L. Jeandet Ribes ${ }^{1,2}$ iD, N. Cubas ${ }^{1}$, H. S. Bhat ${ }^{3}$, and P. Steer ${ }^{2}$ iD \\ ${ }^{1}$ Institut des Sciences de la Terre Paris, ISTeP UMR 7193, Sorbonne Université, CNRS-INSU, Paris, France, ${ }^{2}$ Géosciences \\ Rennes-UMR 6118, Univ Rennes, CNRS, Rennes, France, ${ }^{3}$ Laboratoire de Géologie, Ecole Normale Supérieure, \\ CNRS-UMR 8538, PSL Research University, Paris, France
}

\section{Introduction}

Over geological timescales, mountain belts classically grow through thrusting and thickening of the Earth's crust under tectonic forces (e.g., Davis et al., 1983). This long-term building results from deformation by viscous, ductile and brittle processes and by frictional slip along major faults, leading to rock uplift over a succession of seismic cycles (King et al., 1988; Le Béon et al., 2014). Mass transfers at the Earth's surface due to erosional processes imply stress changes at depth. According to numerical modeling, these stress changes partly control the size and long-term deformation of mountain ranges (Dahlen \& Barr, 1989; Thieulot et al., 2014; Whipple, 2009; Willett, 1999). At shorter timescales (<1 Myr), erosion and sedimentation are also suspected to affect fault slip rate (Calais et al., 2010; Cattin \& Avouac, 2000; Theunissen \& Huismans, 2019; Vernant et al., 2013).

At a seismic cycle timescale (1-1,000 years), mountain building is punctuated by rare but catastrophic tectonic and erosional events affecting the long-term landscape evolution. Succession of earthquakes induces permanent deformation (Simpson, 2015) and large erosional events represent a major contributor to long-term erosion rates (Kirchner et al., 2001; Marc et al., 2019). However, the potential influence of such sudden erosional processes on seismicity is still poorly understood.

The seasonal variations of snowload, precipitation, or atmospheric pressure are known to modulate static stresses at an annual timescale (e.g., Heki, 2003). Although the variation of stress induced by these surface processes is small compared to earthquake stress drop (e.g., Shaw, 2013) or tectonic loading (e.g., Townend \& Zoback, 2004), they do modulate the background seismicity along most tectonically active settings (Bollinger et al., 2007; Christiansen et al., 2007; Gao et al., 2000; Heki, 2003). The periodicity of these variations is likely a major parameter (Ader et al., 2014).

In mountainous areas, hillslopes regularly experience catastrophic erosional events triggered by large earthquakes or rainfall events. These sudden events, associated with numerous landslides, mobilize a large volume (up to several cubic kilometers) of sediments (Keefer, 1994; Marc et al., 2016) that will ultimately be evacuated by rivers. Using an elastic half-space model, Steer et al. (2014) proposed that the erosion rates of active tectonic settings such as Taiwan should be high enough to induce static stress variations of 0.01 to $1 \mathrm{MPa}$ within the interseismic phase in the first few kilometers of the crust. This variation is suggested to be large enough to affect regional seismicity. However, the seismicity response to sudden erosional events is expected to strongly depend on the timing of evacuation of landslide-driven sediments. This timescale is

(C)2020. American Geophysical Union. All Rights Reserved. 
(a)

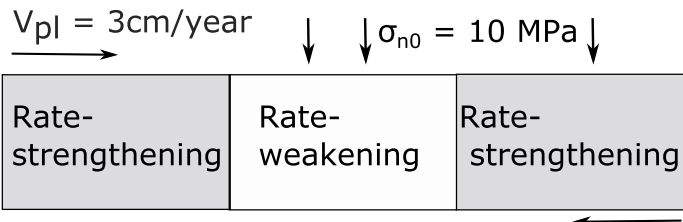

(b)

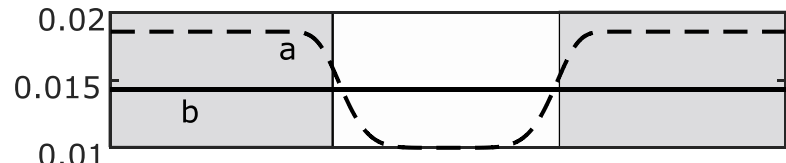

(c)

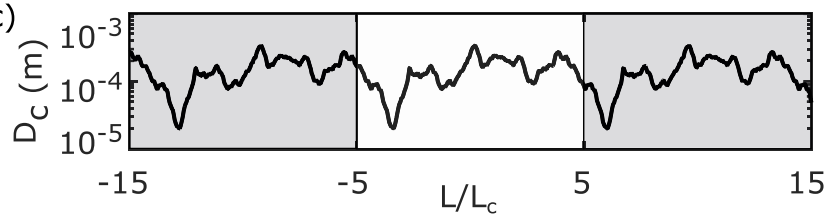

(d)

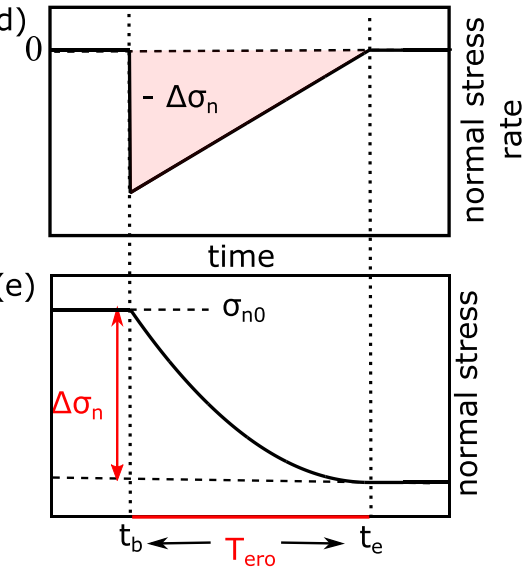

Figure 1. Numerical setup used in this study. (a) Schematic of the simulated fault. Slip weakening acts over the central portion of the fault, of length $10 \times L_{c}$. The fault is loaded at a plate velocity $V_{\mathrm{pl}}$ of $3 \mathrm{~cm} /$ year and the normal stress $\sigma_{n}$ acts over the entire fault. (b, c) Along-strike distribution of friction parameters (b) and critical distance $D_{c}$ (c). Normal stress rate (d) and normal stress (e) temporal variation implemented in QDYN to model one large erosional event. Before the erosional event, the normal stress is $\sigma_{n 0}$. Erosion begins at $t_{b}$. A quantity $\Delta \sigma_{n}$ is removed over a period $T_{\text {ero }}$ until a new background value of normal stress is reached at $t_{e}$.

particularly difficult to constrain since many factors are in play (Croissant et al., 2019). These include landslide connectivity to the drainage network (Li et al., 2016), river dynamics (Croissant et al., 2017; Yanites et al., 2010), and the grain size distribution of landslide sediments (Cowie et al., 2008; Egholm et al., 2013; Sklar \& Dietrich, 2006). This complexity led to estimations of evacuation timescales ranging from centuries (Stolle et al., 2018; Yanites et al., 2010) to only years to decades for suspended load (Hovius et al., 2011) or coarse sediment (Croissant et al., 2017; Howarth et al., 2012). In any case, this evacuation timescale is roughly smaller or equal to the typical duration of a seismic cycle (Chen et al., 2007; Shimazaki \& Nakata, 1980; Sieh et al., 1989).

A relationship between a catastrophic erosional event and regional seismicity has been suggested for the Typhoon Morakot which struck Taiwan in 2009 (Steer et al., 2020). This typhoon triggered 10,000 landslides and removed about $1.2 \mathrm{~km}^{3}$ of sediments from the hillslopes (Marc et al., 2019). The authors reported an increase of both earthquake frequency and $b$ value (i.e., an increase in the proportion of small earthquakes compared to large ones) directly following the typhoon and lasting for at least 2.5 years.

We here investigate if a stress change induced by the removal, over a certain duration, of the sediments following a sudden large erosional event could modify the seismicity of the neighboring crustal faults as suggested in Taiwan. Since this requires consideration of the fault response to transient shear stress increase, or normal stress decrease (Steer et al., 2014), it is necessary to account for the time dependency of fault friction. Simple static stress change calculations offer limited comprehension of the problem (Ader et al., 2014). Therefore, we here use a numerical model considering the general case of a single fault embedded in an elastic medium obeying a rate-and-state friction law (Dieterich, 1979; Rice, 1993; Ruina, 1983). The fault is subjected to a normal stress decrease applied over a certain erosional time, and we explore the resulting seismicity rate and earthquake size distribution.

\section{Methods}

We use QDYN (Luo, Ampuero, Galvez, et al., 2017), a boundary element model that simulates fault slip under a quasi-dynamic approximation (i.e., quasistatic elasticity with radiation damping). Its adaptive time stepping enables to simulate earthquake cycles including seismic and aseismic slip. We considered a 1D, mode II fault embedded in an elastic medium (Figure 1). One could also model this fault as a mode III rupture, with purely out-of-plane displacement. However, for a planar fault, there is only change in shear traction during a rupture, regardless of the mode of the rupture. Between mode II and mode III, the shear traction changes 
differ from each other, by a constant factor associated with the elastic modulus. Thus, for planar faults, we don't expect any difference in the dynamics of a rupture, regardless of the mode. We further assume that our study also applies to reverse faults, since they are well approximated by a mode II rupture at depth, where interactions of the seismic waves with the free surface can be ignored (Madariaga, 2003; Oglesby et al., 1998).

The friction acting on the fault interface obeys a rate-and-state friction law (Marone, 1998):

$$
\tau=\sigma_{n}\left[\mu_{0}+a \log \left(\frac{V}{V_{0}}\right)+b \log \left(\frac{\theta V_{0}}{D_{c}}\right)\right]
$$

where $\tau$ is the shear strength, $\sigma_{n}$ the applied normal stress, $\mu_{0}$ the friction coefficient corresponding to the reference slip rate $V_{0}, \theta$ a state variable, and $D_{c}$ a characteristic slip distance for state variable evolution. The $a$ and $b$ parameters describe the rate and state dependencies, respectively. The state variable? varies according to slip (Rice \& Ruina, 1983). Laboratory experiments (Hong \& Marone, 2005; Kilgore et al., 2017; Linker \& Dieterich, 1992; Shreedharan et al., 2019) and theoretical analysis (Molinari \& Perfettini, 2017) have shown that normal stress variations can contribute to the frictional state. However, since normal stress does not vary with slip in our models due to the flat fault geometry, we use the simple aging law (Rice \& Ruina, 1983):

$$
\dot{\theta}=1-\frac{V \theta}{D_{c}}
$$

The fault is infinite in fault-perpendicular direction and includes a seismogenic patch with rate-weakening (RW) properties $(a-b<0)$ surrounded by two rate-strengthening (RS) areas $(a-b>0)$ of the same size (Figures 1a and 1b). The length of the seismogenic patch is set to be 10 times the nucleation size (Rubin \& Ampuero, 2005), which leads to a fault length of $17 \mathrm{~km}$. The fault is discretized into cells of about $0.5 \mathrm{~m}$ in size to ensure the resolution of the cohesive zone (Lapusta \& Liu, 2009) (see supporting information).

Frictional parameters and boundary conditions are set to commonly used values (e.g., Ader et al., 2014). The value of $b$ is 0.014 and $a$ varies from 0.02 in the RS domain to 0.01 in the RW zone $(a / b=0.7)$. The steady-state frictional properties are constant along the fault $\left(\mu_{0}=0.6\right.$ and $\left.V_{0}=10^{-9} \mathrm{~m} \cdot \mathrm{s}^{-1}\right)$ and the medium has a shear modulus of $G=30 \mathrm{GPa}$. The fault is loaded at a velocity $V_{\mathrm{pl}}$ of $3 \mathrm{~cm} /$ year and the applied normal stress is of $10 \mathrm{MPa}$, consistent with a depth of a few kilometers (Suppe, 2014). Quasi-dynamic simulations of a seismogenic patch with constant frictional properties produce one characteristic, repeating event (Rice, 1993). Since multiple fault models are still under progress (Romanet et al., 2018), we choose to simulate a spatiotemporal complexity by varying the critical distance $D_{c}$ (Aochi \& Ide, 2004; Hillers et al., 2007; Ide \& Aochi, 2005). To obtain various earthquake magnitudes with a single fault, we vary $D_{c}$ along strike from values of $2 \times 10^{-5}$ to $3.4 \times 10^{-4} \mathrm{~m}$ following a self-similar pattern in both RW and RS patches (Figure 1c).

An erosional event is defined by the amplitude of the stress variation, its duration, and the functional relationship of this variation. Inferred erosion-induced increase in Coulomb stress ranges from 0.01 to $1 \mathrm{MPa}$ (Steer et al., 2014) and estimates of the duration of an erosional event vary from 1 to 10 years (Croissant et al., 2017; Hovius et al., 2011), to several centuries (Stolle et al., 2018; Yanites et al., 2010). Moreover, a sharp erosion increase followed by a linear decrease down to its background value has been observed just after the Chi-Chi earthquake by Hovius et al. (2011).

We thus run simulations including a sudden drop in normal stress rate (Figure 1d) followed by a linear increase taking place over a period $T_{\text {ero }}$, with a total removed normal stress integrated over $T_{\text {ero }}$ of $\Delta \sigma_{n}$ (Figure 1e). We test $\Delta \sigma_{n}$ ranging from 0.01 to $1 \mathrm{MPa}$ and $T_{\text {ero }}$ from $10^{-3}$ to 10 times the duration of one modeled seismic cycle (2.2 years). The corresponding mean normal stress rate thus varies from 6.34 (for $\Delta \sigma_{n}=1 \mathrm{MPa}, T_{\text {ero }}=0.01$ years) to $1.5 \times 10^{-5} \mathrm{~Pa} / \mathrm{s}\left(\Delta \sigma_{n}=0.01 \mathrm{MPa}, T_{\text {ero }}=20.48\right.$ years $)$, that is, between 5 and $10^{-5}$ times the background loading rate imposed by the plate velocity $(\sim 1.2 \mathrm{~Pa} / \mathrm{s})$. The onset of the normal stress perturbation is implemented during the interseismic period of a stabilized cycle (when the fault produces regular events). In the following, we use "erosion" and "normal stress decrease" to mean the same physical process. 

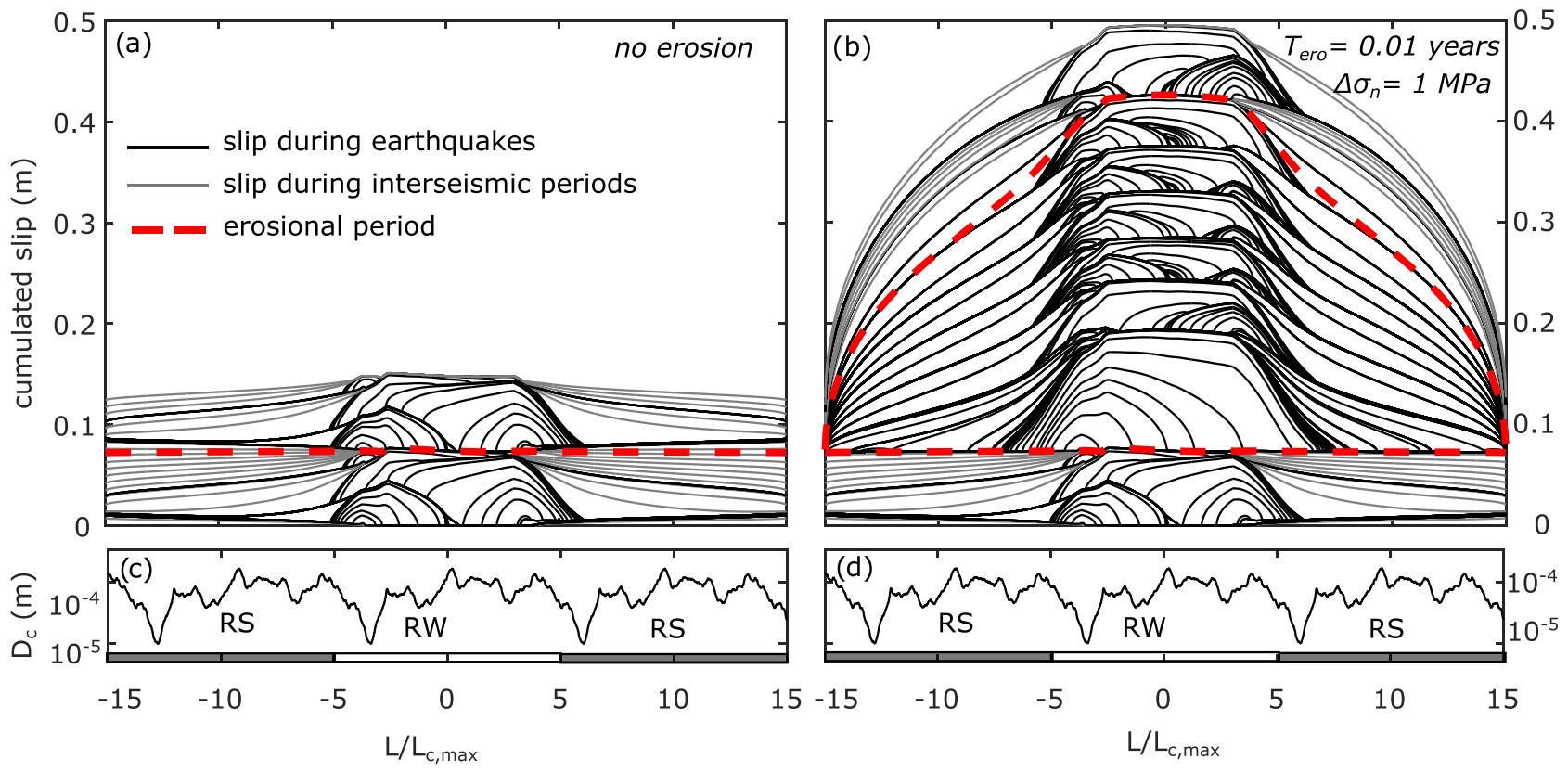

Figure 2. Cumulated slip along strike during 4 years for (a) the undisturbed fault and (b) the fault under $\Delta \sigma_{n}=1 \mathrm{MPa}$ and $T_{\text {ero }}=0.01$ years. The slip is plotted every $0.5 \mathrm{~s}$ during seismic events and every 0.2 years during interseismic periods. The slip at time $t_{b}$ is plotted in dashed red line, and the slip at $t_{e}$ is plotted in plain red line in (b). (c, d) $D_{c}$ distribution along the rate-strengthening (RS) and rate-weakening (RW) areas.

For each simulation, we build an earthquake catalogue by isolating seismic events using a moment rate threshold $\dot{M}_{0}$ of $10^{8}$ dyn. $\mathrm{cm}^{-2} \cdot \mathrm{s}^{-1}$ and we compute the magnitude of individual earthquakes assuming a fault width of $10 \mathrm{~km}$ (supporting information).

\section{Results}

Without any normal stress perturbation, we obtain a regular sequence composed of three characteristic earthquakes (Figure 2a) that nucleate at an edge of the RW patch loaded by RS regions. The magnitude of these three typical events are of 4.85, 5.20, and 4.18, respectively (Figure 3). The second event is a characteristic large earthquake that regularly ruptures the entire seismogenic area, with a recurrence time of 2.2 years. Therefore, in the following, the sequence is called "seismic cycle."

For a normal stress perturbation of $\Delta \sigma_{n}=1 \mathrm{MPa}$ applied over a $T_{\text {ero }}=0.08$ years, the seismicity rate increases during the erosional period (Figure $2 b)$. The new sequence starts with a large event $\left(\mathrm{M}_{\mathrm{w}}=5.34\right.$ ), that ruptures the entire patch. It is followed by a succession of earthquakes of various magnitudes (between 4.01 and 5.22), with some small events nucleating on the right portion of the fault, which is not characterized by small $D_{c}$ values (Figure $2 \mathrm{~d}$ ).

To characterize the size distribution of dynamic events, we arbitrarily bin the earthquakes generated during $T_{\text {ero }}$ into two categories: small $\left(\mathrm{M}_{\mathrm{w}}>4.5\right)$ and large $\left(\mathrm{M}_{\mathrm{w}}<4.5\right)$ ruptures. We first compare two end-member simulations displaying different response in terms of earthquake magnitude (Figure 3). For $T_{\text {ero }}=20.48$ years, the earthquake frequency increases by a factor close to 2 during approximately 10 years and then progressively returns back to its initial level (Figures $3 \mathrm{a}$ and $3 \mathrm{c}$ ). The characteristic sequence is more frequent in time with the same magnitudes. For $T_{\text {ero }}=0.01$ years, we observe a significant change in the distribution of earthquake magnitudes during erosion (Figure 3d). Small events are increased by $60 \%$ and are more frequent than larger events (Figure $3 b$ ).

We now show results obtained for simulations with $\Delta \sigma_{n}$ varying from 0.01 to $1 \mathrm{MPa}$ and $T_{\text {ero }}$ from 7 hours to 20 years, corresponding to a ratio $T_{\text {ero }} / T_{\text {cycle }}$ ratio ranging from $4 \times 10^{-4}$ to 10 (Figure 4 ). For each model, we plot the number of earthquakes $N$ (Figure $4 a$ ) and the cumulated moment (Figure $4 \mathrm{~b}$ ) during the erosional period. We then compute the average earthquake frequency obtained during erosion (i.e., $N / T_{\text {ero }}$ ) 


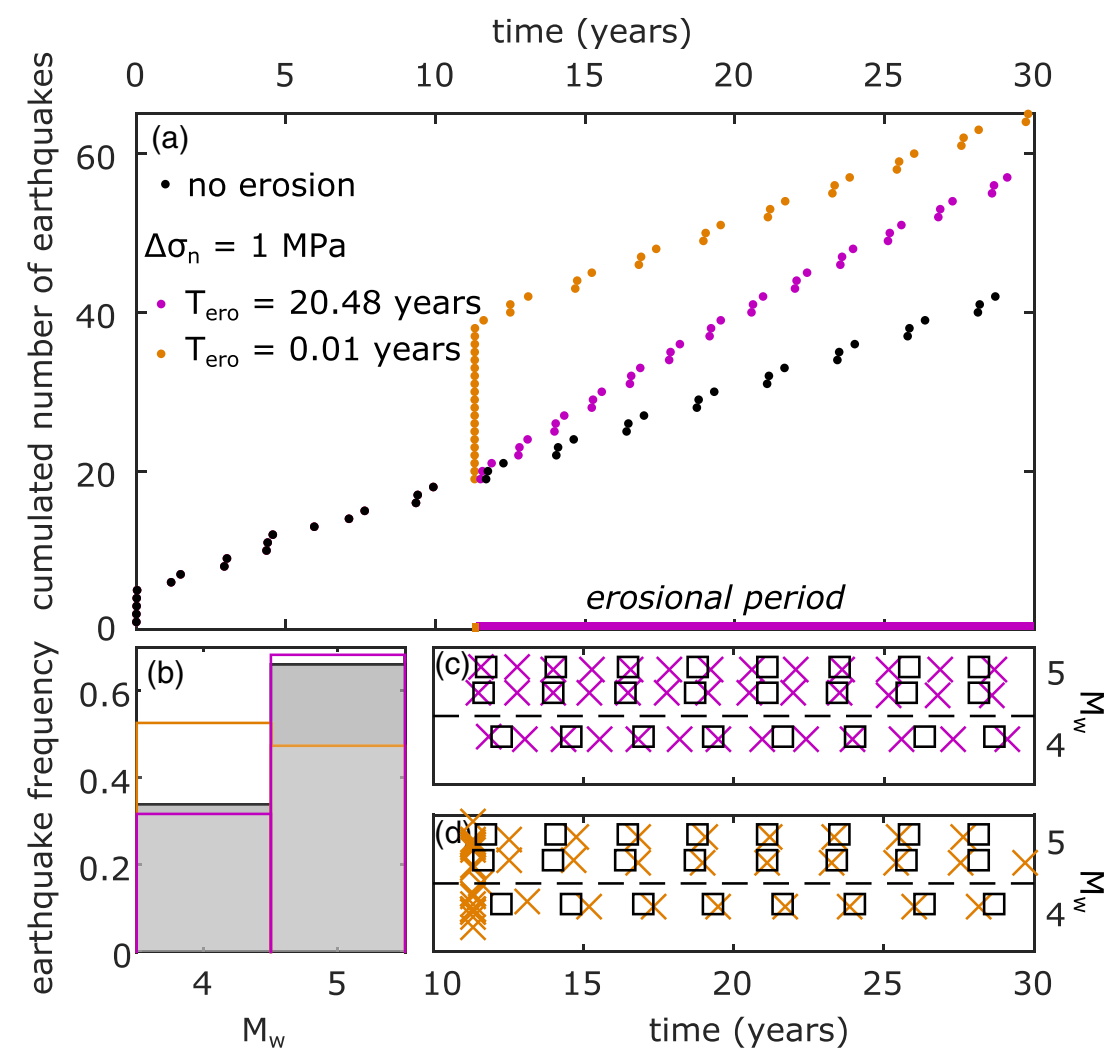

Figure 3. (a) Cumulated number of earthquakes for $T_{\text {ero }}=0.01$ year and 20.48 years with $\Delta \sigma_{n}=1 \mathrm{MPa}$ and for the undisturbed fault. (b) Proportion of small and large earthquakes during the erosional period (colored edges), for the two scenarios shown in (a). The gray bars show the earthquake distribution for the undisturbed fault. Panels (c) and (d) show time evolution of earthquake magnitudes for $T_{\text {ero }}=20.48$ and 0.01 years, compared to the undisturbed fault (dark squares). The horizontal dotted lines show the edge of the bins used in (b).

normalized by the earthquake frequency observed during an undisturbed seismic cycle (i.e., $3 / T_{\text {cycle }}$ ) (Figure 4c). Earthquake statistics during the erosional event are also given, as a function of the ratio $T_{\text {ero }}$ over either the duration of a standard seismic cycle $\left(T_{\text {cycle }}\right)$ of the undisturbed fault (Figure $\left.4 \mathrm{c}\right)$ or the nucleation time ( $T_{\text {nuc }}$, Figure $S 4$ ) of a characteristic earthquake (Figure $4 d$ ).

At first order, the number $N$ of earthquakes during erosion increases with $\Delta \sigma_{n}$ (Figure 4a). In turn, the cumulated seismic moment during the erosional period follows the same pattern (Figure 4b). For $\Delta \sigma_{n}=0.1$ and $0.01 \mathrm{MPa}$, very low $T_{\text {ero }}$ are too short-lived to enable any triggering during the period of erosion. At second order, we can identify two different regimes depending on the duration of the erosional event. For $T_{\text {ero }} / T_{\text {cycle }}>1, N$ increases when increasing $T_{\text {ero }}$, whereas it remains roughly constant for $T_{\text {ero }} / T_{\text {cycle }}<1$.

The earthquake frequency also increases with increasing $\Delta \sigma_{n}$ (Figure 4c). Compared to the reference case without erosion, it increases by a factor of 1 to 2 for $\Delta \sigma_{n}=0.01 \mathrm{MPa}, 1$ to 100 for $\Delta \sigma_{n}=$ $0.1 \mathrm{MPa}$, and 1 to 10,000 for $\Delta \sigma_{n}=1 \mathrm{Mpa}$. For a given $\Delta \sigma_{n}$, earthquake rate increases with decreasing $T_{\text {ero }}$. When erosion is shorter than a seismic cycle, earthquake frequency increases significantly, by a factor of 2 for $T_{\text {ero }} / T_{\text {cycle }}<2$ with $\Delta \sigma_{n}=1 \mathrm{MPa}$, or $T_{\text {ero }} / T_{\text {cycle }}<0.5$ with $\Delta \sigma_{n}=0.1$ or $0.01 \mathrm{MPa}$.

The proportion of large $\left(\mathrm{M}_{\mathrm{w}}>4.5\right)$ and small $\left(\mathrm{M}_{\mathrm{w}}<4.5\right)$ earthquakes during erosion varies as shown for the models with $\Delta \sigma_{n}=1 \mathrm{MPa}$ (Figure $4 \mathrm{~d}$ ). For $T_{\text {ero }}>10 T_{\text {nuc }}$, the size distribution of earthquakes does not vary significantly from the distribution of the undisturbed fault (when large earthquakes represent two thirds of all rupture events). However, for $T_{\text {ero }}<10 T_{\text {nuc }}$, the proportion of earthquakes is inverted with a significant increase of small events and a decrease of the larger ones. This variation is not observed for small $\Delta \sigma_{n}(0.1$ and $0.01 \mathrm{Mpa}$ ) (Figure S2). 

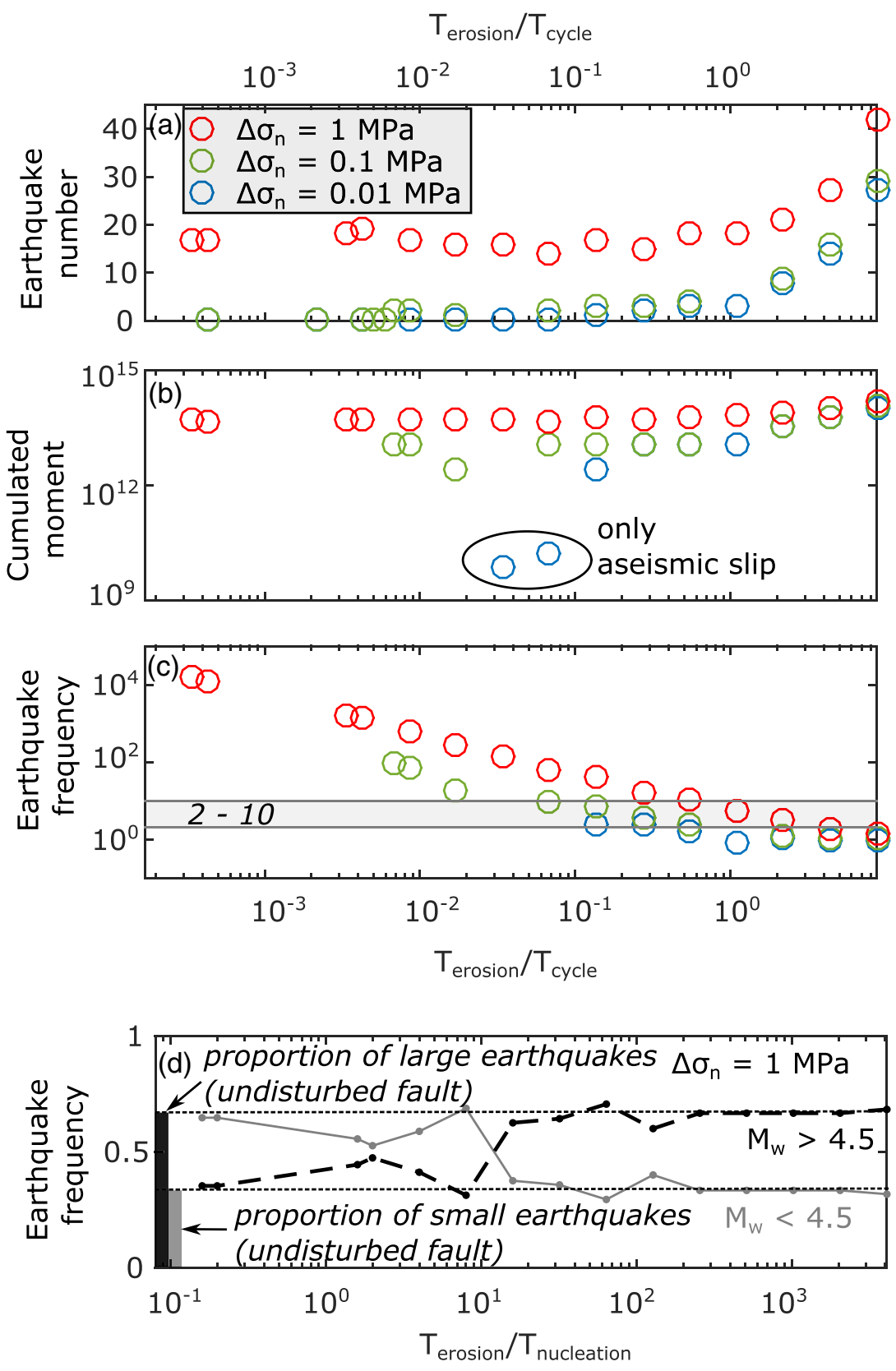

Figure 4. (a) Number of earthquakes $N$ during the erosional event, as a function of $T_{\text {ero }}$ normalized by the duration of an undisturbed seismic cycle. (b) Cumulated moment during erosion. The two models quoted "aseismic slip" correspond to two scenarios in which no earthquake occurred. (c) Earthquake rate during the erosional period, normalized by the rate of the undisturbed fault. The shaded area shows the models for which the seismicity rate increases by a factor of 2 to 10 compared to the undisturbed seismicity rate. (d) Proportion of large $\left(\mathrm{M}_{\mathrm{w}}>4.5\right.$, dark line $)$ and small $\left(\mathrm{M}_{\mathrm{w}}<4.5\right.$, gray line) earthquakes during erosion for each model with $\Delta \sigma_{n}=1 \mathrm{MPa}$, as a function of $T_{\text {ero }}$ normalized by the earthquake nucleation time. The dotted lines show the proportion of small and large earthquakes in the case of the undisturbed fault.

\section{Discussion and Concluding Remarks}

Using quasi-dynamic models of earthquake cycle on a mode II fault, we here show that a large erosional event simulated by a variation of the normal stress $\Delta \sigma_{n}$ over a certain time $T_{\text {ero }}$ can significantly affect earthquake statistics. 
An erosional event can result in a clear increase in earthquake frequency. For large $\Delta \sigma_{n}$, the fault response is quite simple as earthquake frequency increases with the rate of normal stress change (i.e., decreasing $T_{\text {ero }}$ ). For smaller $\Delta \sigma_{n}$, our results illustrate the complexity of fault response to transient stress changes. For example, stress variation with low magnitudes $\left(\Delta \sigma_{n}=0.01 \mathrm{MPa}\right)$ occurring within a too short period does not trigger any earthquake (Figure 4a). If the same total normal stress is removed over a longer period, it triggers aseismic or seismic slip during erosion (Figure $4 \mathrm{~b}$ ). This suggests that within a population of faults close to their critical state, even small normal stress variations could trigger numerous earthquakes within the years following a large erosional event.

In our model (Equation 2), normal stress variation itself does not contribute to the evolution of frictional state (e.g., Linker \& Dieterich, 1992). Although we do not expect the Linker-Dieterich effect to significantly change our results, we suspect that it would enhance the erosion-induced shear strength decrease and then the modeled seismicity. Moreover, poroelasticity, thermal pressurization, and dilatant strengthening act on the fault strength and could also enhance seismicity or compete with each other (e.g., Segall et al., 2010). Surface unloading would also induce shear stress variations. In the case of a reverse fault, we could expect the erosion-induced shear stress increase (Steer et al., 2014) to enhance the observed earthquake production (e.g., Hawthorne \& Rubin, 2013; Johnson et al., 2017; Luo \& Liu, 2019).

We also show that under high and rapid enough $\Delta \sigma_{n}$, a single fault is likely to produce more numerous small ruptures, relative to large ones. This observation could be biased by our chosen setup. First, the lowest $D_{c}$ areas are located at the edge of the RW patch (Figures 1b and 1c). However, Ader et al. (2014) noted a similar change in the distribution of events following a step-like increase in shear stress on a homogeneous fault. Moreover, running the same model on a fault with another random pattern of $D_{c}$ with same roughness leads to the same observation (Figure S3). The correlation length also probably influences the overall distribution of seismicity. This effect needs to be further investigated.

We thus suspect that under a larger normal stress decrease, the reduction of slip induced by a smaller shear stress drop associated with a reduction in critical stiffness (e.g., Leeman et al., 2016) contributes to reducing the proportion of large earthquakes. Moreover, rapid normal stress variations, along with a spatially heterogeneous $D_{c}$, could significantly change nucleation length scales allowing for the fault to rupture with multiple smaller ruptures than the canonical case. To confirm our hypothesis, 3D modeling and simulation of a wide range of magnitudes could be carried out (Hillers et al., 2007; Luo, Ampuero, Miyakoshi, et al., 2017).

The earthquake rate increases even for very small $\Delta \sigma_{n}$ as long as $T_{\text {ero }}$ is short enough compared to the duration of an undisturbed seismic cycle. The dependency of fault response to the magnitude and frequency of environmental stress change has already been documented.

Earthquake-induced sudden stress changes below 0.01 MPa were observed to be insufficient to trigger seismicity (Hardebeck et al., 1998; Reasenberg \& Simpson, 1992). Hawthorne and Rubin (2013) have demonstrated tidal modulation of slow slip events. However, earthquake rate does not systematically display variations at tidal period (Cochran et al., 2004; Vidale et al., 1998), despite the similar magnitude of static stress changes due to hydrological cycle and Earth's tides.

Such period dependency has also been observed in laboratory experiments (Beeler \& Lockner, 2003; Lockner \& Beeler, 1999). For high frequencies, the fault response is amplitude-dependent, while for low frequencies, it rather depends on perturbation frequency and amplitude (Boettcher, 2004). This transition has been interpreted as the time necessary to reach the critical distance $D_{c}$. Numerical modeling (Ader et al., 2014) shows a resonance effect in the response of a finite fault to harmonic shear stress variations, which is more important than for 1D spring slider models with rate-and-state friction laws (Perfettini et al., 2001). Kaneko and Lapusta (2008) and Ader et al. (2014) pointed out similar observations studying a finite fault response to a static shear stress step.

In this study, we show that the fault response to one transient stress change is also period-dependent. We observe a range of erosion periods for which a normal stress variation of $0.1 \%$ to $1 \%$ can significantly accelerate seismicity on our modeled fault. This range is bounded by the typical timescales of the modeled seismic cycle and earthquake nucleation. Fault response is likely to depend on plate velocity, which is inversely proportionally related to the recurrence time of earthquakes (Ader et al., 2014). Analogously, Ader et al. (2014) noted an inversely proportional relationship between the loading rate and the characteristic response time of 
seismicity, when considering either sinusoidal or step-like stress variation. Therefore, our finding that fault response is greater for an erosion period related to the recurrence time of large earthquake in our model should not change using a different loading rate.

In nature, landscape response to large erosional events is likely to occur at a timescale ranging from a few years to several decades (Croissant et al., 2017; Hovius et al., 2011; Howarth et al., 2012). Moreover, sediment export is expected to be most efficient and to significantly exceed background erosion rates over the first years following the perturbation (Croissant et al., 2017; Hovius et al., 2011). Moreover, earthquake nucleation takes months to a year (Beeler \& Lockner, 2003; Savage \& Marone, 2007), and seismic cycles last between about 100 to 1,000 years (e.g., Chen et al., 2007). Hence, the timescale of an erosional event ranges between the nucleation and the seismic cycle timescales. Therefore, our results suggest that one large erosional event is likely to increase seismicity by at least a factor of 2 , if it implies normal stress decrease of at least $0.1 \%$ from the background normal stress. For example, overpressured faults with a normal stress of about $25 \mathrm{MPa}$ below 2-km depth (Suppe, 2014) would be sensitive to an erosional event of a few decades up to 5-km depth, considering the induced static stress change (Steer et al., 2014). This corroborate previous observation of an increase in earthquake frequency by a factor of 2 and a $b$ value increase in the years following Typhoon Morakot (Steer et al., 2020).

Normal stress change due to erosion is different from a sudden static shear stress change induced by a mainshock, because it is likely to be transient. However, contrary to hydrological, tidal, or atmospheric forcing, surface processes such as erosion and sedimentation are not periodic. Therefore, the induced stress changes are likely to cumulate over time. By showing that erosion can significantly trigger seismicity at seismic cycle timescale, our results build upon previous results showing the impact of erosion on static stress changes (Steer et al., 2014). They also suggest that such cumulative processes, including large erosional events, but also glacial melting, or human-induced water extraction, can significantly contribute to the deformation of the crust at least in its shallow part.

\section{References}

Ader, T. J., Lapusta, N., Avouac, J.-P., \& Ampuero, J.-P. (2014). Response of rate-and-state seismogenic faults to harmonic shear-stress perturbations. Geophysical Journal International, 198, 385-413. https://doi.org/10.1093/gji/ggu144

Aochi, H., \& Ide, S. (2004). Numerical study on multi-scaling earthquake rupture. Geophysical Research Letters, 31, L02606. https://doi.org/ 10.1029/2003GL018708

Beeler, N. M., \& Lockner, D. A. (2003). Why earthquakes correlate weakly with the solid Earth tides: Effects of periodic stress on the rate and probability of earthquake occurrence. Journal of Geophysical Research, 108(B8), 2391. https://doi.org/10.1029/2001JB001518

Boettcher, M. S. (2004). Effects of normal stress variation on the strength and stability of creeping faults. Journal of Geophysical Research, 109, B03406. https://doi.org/10.1029/2003JB002824

Bollinger, L., Perrier, F., Avouac, J.-P., Sapkota, S., Gautam, U., \& Tiwari, D. R. (2007). Seasonal modulation of seismicity in the Himalaya of Nepal. Geophysical Research Letters, 34, L08304. https://doi.org/10.1029/2006GL029192

Calais, E., Freed, A. M., Arsdale, R. V., \& Stein, S. (2010). Triggering of New Madrid seismicity by late-Pleistocene erosion. Nature, 466(7306), 608-611. https://doi.org/10.1038/nature09258

Cattin, R., \& Avouac, J. P. (2000). Modeling mountain building and the seismic cycle in the Himalaya of Nepal. Journal of Geophysical Research, 105(B6), 13,389-13,407. https://doi.org/10.1029/2000JB900032

Chen, W.-S., Yang, C.-C., Yen, I.-C., Lee, L.-S., Lee, K.-J., Yang, H.-C., et al. (2007). Late Holocene paleoseismicity of the southern part of the Chelungpu fault in central Taiwan: Evidence from the Chushan excavation site. Bulletin of the Seismological Society of America, 97(1B), 1-13. https://doi.org/10.1785/0120050161

Christiansen, L. B., Hurwitz, S., \& Ingebritsen, S. E. (2007). Annual modulation of seismicity along the San Andreas Fault near Parkfield, CA. Geophysical Research Letters, 34, L04306. https://doi.org/10.1029/2006GL028634

Cochran, E. S., Vidale, J. E., \& Tanaka, S. (2004). Earth tides can trigger shallow thrust fault earthquakes. Science, 306(5699), 1164-1166. https://doi.org/10.1126/science.1103961

Cowie, P. A., Whittaker, A. C., Attal, M., Roberts, G., Tucker, G. E., \& Ganas, A. (2008). New constraints on sediment-flux-dependent river incision: Implications for extracting tectonic signals from river profiles. Geology, 36(7), 535-538. https://doi.org/10.1130/ G24681A.1

Croissant, T., Lague, D., Steer, P., \& Davy, P. (2017). Rapid post-seismic landslide evacuation boosted by dynamic river width. Nature Geoscience, 10, 680-684. https://doi.org/10.1038/ngeo3005

Croissant, T., Steer, P., Lague, D., Davy, P., Jeandet, L., \& Hilton, R. G. (2019). Seismic cycles, earthquakes, landslides and sediment fluxes: Linking tectonics to surface processes using a reduced-complexity model. Geomorphology, 339, 87-103. https://doi.org/10.1016/j. geomorph.2019.04.017

Dahlen, F., \& Barr, T. D. (1989). Brittle frictional mountain building: 1. Deformation and mechanical energy budget. Journal of Geophysical Research, 94(B4), 3906-3922. https://doi.org/10.1029/JB094iB04p03906

Davis, D., Suppe, J., \& Dahlen, F. A. (1983). Mechanics of fold-and-thrust belts and accretionary wedges. Journal of Geophysical Research, 88(B2), 1153-1172. https://doi.org/10.1029/JB088iB02p01153

Dieterich, J. H. (1979). Modeling of rock friction: 1. Experimental results and constitutive equations. Journal of Geophysical Research, 84(B5), 2161-2168. https://doi.org/10.1029/JB084iB05p02161 
Egholm, D. L., Knudsen, M. F., \& Sandiford, M. (2013). Lifespan of mountain ranges scaled by feedbacks between landsliding and erosion by rivers. Nature, 498, 475-478. https://doi.org/10.1038/nature12218

Gao, S. S., Silver, P. G., Linde, A. T., \& Sacks, I. S. (2000). Annual modulation of triggered seismicity following the 1992 Landers earthquake in California. Nature, 406(6795), 500-504. https://doi.org/10.1038/35020045

Hardebeck, J. L., Nazareth, J. J., \& Hauksson, E. (1998). The static stress change triggering model: Constraints from two southern California aftershock sequences. Journal of Geophysical Research, 103(B10), 24,427-24,437. https://doi.org/10.1029/98JB00573

Hawthorne, J. C., \& Rubin, A. M. (2013). Tidal modulation and back-propagating fronts in slow slip events simulated with a velocity-weakening to velocity-strengthening friction law: Tidal forcing in simulated slow slip. Journal of Geophysical Research: Solid Earth, 118, 1216-1239. https://doi.org/10.1002/jgrb.50107

Heki, K. (2003). Snow load and seasonal variation of earthquake occurrence in Japan. Earth and Planetary Science Letters, 207(1-4), 159-164. https://doi.org/10.1016/S0012-821X(02)01148-2

Hillers, G., Mai, P. M., Ben-Zion, Y., \& Ampuero, J.-P. (2007). Statistical properties of seismicity of fault zones at different evolutionary stages. Geophysical Journal International, 169(2), 515-533. https://doi.org/10.1111/j.1365-246X.2006.03275.x

Hong, T., \& Marone, C. (2005). Effects of normal stress perturbations on the frictional properties of simulated faults: Normal stress on faults. Geochemistry, Geophysics, Geosystems, 6, Q03012. https://doi.org/10.1029/2004GC000821

Hovius, N., Meunier, P., Lin, C.-W., Chen, H., Chen, Y.-G., Dadson, S., et al. (2011). Prolonged seismically induced erosion and the mass balance of a large earthquake. Earth and Planetary Science Letters, 304(3), 347-355.

Howarth, J. D., Fitzsimons, S. J., Norris, R. J., \& Jacobsen, G. E. (2012). Lake sediments record cycles of sediment flux driven by large earthquakes on the Alpine fault, New Zealand. Geology, 40(12), 1091-1094. https://doi.org/10.1130/G33486.1

Ide, S., \& Aochi, H. (2005). Earthquakes as multiscale dynamic ruptures with heterogeneous fracture surface energy. Journal of Geophysical Research, 110, B11303. https://doi.org/10.1029/2004JB003591

Johnson, C. W., Fu, Y., \& Bürgmann, R. (2017). Seasonal water storage, stress modulation, and California seismicity. Science, 356, 1161-1164. https://doi.org/10.1126/science.aak9547

Kaneko, Y., \& Lapusta, N. (2008). Variability of earthquake nucleation in continuum models of rate-and-state faults and implications for aftershock rates. Journal of Geophysical Research, 113, B12312. https://doi.org/10.1029/2007JB005154

Keefer, D. K. (1994). The importance of earthquake-induced landslides to long-term slope erosion and slope-failure hazards in seismically active regions. Geomorphology, 10(1-4), 265-284. https://doi.org/10.1016/0169-555X(94)90021-3

Kilgore, B., Beeler, N. M., Lozos, J., \& Oglesby, D. (2017). Rock friction under variable normal stress. Journal of Geophysical Research: Solid Earth, 122, 7042-7075. https://doi.org/10.1002/2017JB014049

King, G. C., Stein, R. S., \& Rundle, J. B. (1988). The growth of geological structures by repeated earthquakes 1 . Conceptual framework Journal of Geophysical Research, 93(B11), 13,307-13,318. https://doi.org/10.1029/JB093iB11p13307

Kirchner, J. W., Finkel, R. C., Riebe, C. S., Granger, D. E., Clayton, J. L., King, J. G., \& Megahan, W. F. (2001). Mountain erosion over 10 yr, 10 ky, and 10 my time scales. Geology, 29(7), 591-594. https://doi.org/10.1130/0091-7613(2001)029<0591:MEOYKY>2.0.CO;2

Lapusta, N., \& Liu, Y. (2009). Three-dimensional boundary integral modeling of spontaneous earthquake sequences and aseismic slip. Journal of Geophysical Research, 114, B09303. https://doi.org/10.1029/2008JB005934

Le Béon, M., Suppe, J., Jaiswal, M. K., Chen, Y.-G., \& Ustaszewski, M. E. (2014). Deciphering cumulative fault slip vectors from fold scarps: Relationships between long-term and coseismic deformations in central Western Taiwan. Journal of Geophysical Research: Solid Earth, 119, 5943-5978. https://doi.org/10.1002/2013JB010794

Leeman, J. R., Saffer, D. M., Scuderi, M. M., \& Marone, C. (2016). Laboratory observations of slow earthquakes and the spectrum of tectonic fault slip modes. Nature Communications, 7, 11104. https://doi.org/10.1038/ncomms11104

Li, G., West, A. J., Densmore, A. L., Hammond, D. E., Jin, Z., Zhang, F., et al. (2016). Connectivity of earthquake-triggered landslides with the fluvial network: Implications for landslide sediment transport after the 2008 Wenchuan earthquake. Journal of Geophysical Research: Earth Surface, 121, 703-724. https://doi.org/10.1002/2015JF003718

Linker, M. F., \& Dieterich, J. H. (1992). Effects of variable normal stress on rock friction: Observations and constitutive equations. Journal of Geophysical Research, 97(B4), 4923-4940. https://doi.org/10.1029/92JB00017

Lockner, D. A., \& Beeler, N. M. (1999). Premonitory slip and tidal triggering of earthquakes. Journal of Geophysical Research, 104(B9), 20,133-20,151. https://doi.org/10.1029/1999JB900205

Luo, Y., Ampuero, J. P., Galvez, P., van den Ende, M., \& Idini, B. (2017). QDYN: A Quasi-DYNamic Earthquake Simulator (V1. 1).

Luo, Y., Ampuero, J.-P., Miyakoshi, K., \& Irikura, K. (2017). Surface rupture effects on earthquake moment-area scaling relations. Pure and Applied Geophysics, 174, 3331-3342. https://doi.org/10.1007/s00024-017-1467-4

Luo, Y., \& Liu, Z. (2019). Slow-slip recurrent pattern changes: Perturbation responding and possible scenarios of precursor toward a megathrust earthquake. Geochemistry, Geophysics, Geosystems, 20, 852-871. https://doi.org/10.1029/2018GC008021

Madariaga, R. (2003). Radiation from a finite reverse fault in a half space. Pure and Applied Geophysics, 160(3-4), 555-577. https://doi.org/ $10.1007 /$ PL00012550

Marc, O., Hovius, N., \& Meunier, P. (2016). The mass balance of earthquakes and earthquake sequences. Geophysical Research Letters, 43, 3708-3716. https://doi.org/10.1002/2016GL068333

Marc, O., Behling, R., Andermann, C., Turowski, J. M., Illien, L., Roessner, S., \& Hovius, N. (2019). Long-term erosion of the Nepal Himalayas by bedrock landsliding: The role of monsoons, earthquakes and giant landslides. Earth Surface Dynamics, 7, 107-128. https:// doi.org/10.5194/esurf-7-107-2019

Marone, C. (1998). Laboratory-derived friction laws and their application to seismic faulting. Annual Review of Earth and Planetary Sciences, 26(1), 643-696. https://doi.org/10.1146/annurev.earth.26.1.643

Molinari, A., \& Perfettini, H. (2017). A micromechanical model of rate and state friction: 2. Effect of shear and normal stress changes: Effect of stress changes on friction. Journal of Geophysical Research: Solid Earth, 122, 2638-2652. https://doi.org/10.1002/2016JB013307

Oglesby, D. D., Archuleta, R. J., \& Nielsen, S. B. (1998). Earthquakes on dipping faults: The effects of broken symmetry. Science, 280(5366), 1055-1059. https://doi.org/10.1126/science.280.5366.1055

Perfettini, H., Schmittbuhl, J., Rice, J. R., \& Cocco, M. (2001). Frictional response induced by time-dependent fluctuations of the normal loading. Journal of Geophysical Research, 106(B7), 13,455-13,472. https://doi.org/10.1029/2000JB900366

Reasenberg, P. A., \& Simpson, R. W. (1992). Response of regional seismicity to the static stress change produced by the Loma Prieta earthquake. Science, 255(5052), 1687-1690. https://doi.org/10.1126/science.255.5052.1687

Rice, J. R., \& Ruina, A. L. (1983). Stability of steady frictional slipping. Journal of Applied Mechanics, 50(2), 343-349. https://doi.org/ $10.1115 / 1.3167042$ 
Rice, J. R. (1993). Spatio-temporal complexity of slip on a fault. Journal of Geophysical Research, 98(B6), 9885-9907. https://doi.org/ 10.1029/93JB00191

Romanet, P., Bhat, H. S., Jolivet, R., \& Madariaga, R. (2018). Fast and slow slip events emerge due to fault geometrical complexity. Geophysical Research Letters, 45, 4809-4819. https://doi.org/10.1029/2018GL077579

Rubin, A. M., \& Ampuero, J.-P. (2005). Earthquake nucleation on (aging) rate and state faults. Journal of Geophysical Research: Solid Earth, 110(B11). https://doi.org/10.1029/2005JB003686

Ruina, A. (1983). Slip instability and state variable friction laws. Journal of Geophysical Research, 88(B12), 10,359-10,370. https://doi.org/ 10.1029/JB088iB12p10359

Savage, H., \& Marone, C. (2007). Effects of shear velocity oscillations on stick-slip behavior in laboratory experiments. Journal of Geophysical Research, 112, B02301. https://doi.org/10.1029/2005JB004238

Segall, P., Rubin, A. M., Bradley, A. M., \& Rice, J. R. (2010). Dilatant strengthening as a mechanism for slow slip events. Journal of Geophysical Research, 115(B12). https://doi.org/10.1029/2010JB007449

Shaw, B. E. (2013). Earthquake surface slip-length data is fit by constant stress drop and is useful for seismic hazard analysis. Bulletin of the Seismological Society of America, 103, 876-893. https://doi.org/10.1785/0120110258

Shimazaki, K., \& Nakata, T. (1980). Time-predictable recurrence model for large earthquakes. Geophysical Research Letters, 7(4), 279-282. https://doi.org/10.1029/GL007i004p00279

Shreedharan, S., Rivière, J., Bhattacharya, P., \& Marone, C. (2019). Frictional state evolution during normal stress perturbations probed with ultrasonic waves. Journal of Geophysical Research: Solid Earth, 124, 5469-5491. https://doi.org/10.1029/2018JB016885

Sieh, K., Stuiver, M., \& Brillinger, D. (1989). A more precise chronology of earthquakes produced by the San Andreas fault in southern California. Journal of Geophysical Research, 94(B1), 603-623. https://doi.org/10.1029/JB094iB01p00603

Simpson, G. (2015). Accumulation of permanent deformation during earthquake cycles on reverse faults. Journal of Geophysical Research: Solid Earth, 120, 1958-1974. https://doi.org/10.1002/2014JB011442

Sklar, L. S., \& Dietrich, W. E. (2006). The role of sediment in controlling steady-state bedrock channel slope: Implications of the saltation-abrasion incision model. Geomorphology, 82(1-2), 58-83. https://doi.org/10.1016/j.geomorph.2005.08.019

Steer, P., Jeandet, L., Cubas, N., Marc, O., Meunier, P., Simoes, M., et al. (2020). Earthquake statistics changed by typhoon-driven erosion Scientific Reports, 10, 10899. https://doi.org/10.1038/s41598-020-67865-y

Steer, P., Simoes, M., Cattin, R., \& Shyu, J. B. H. (2014). Erosion influences the seismicity of active thrust faults. Nature Communications, 5 , 5564. https://doi.org/10.1038/ncomms6564

Stolle, A., Schwanghart, W., Andermann, C., Bernhardt, A., Fort, M., Jansen, J. D., et al. (2018). Protracted river response to medieval earthquakes. Earth Surface Processes and Landforms, 44, 331-341. https://doi.org/10.1002/esp.4517

Suppe, J. (2014). Fluid overpressures and strength of the sedimentary upper crust. Journal of Structural Geology, 69, 481-492. https://doi. org/10.1016/j.jsg.2014.07.009

Theunissen, T., \& Huismans, R. S. (2019). Long-term coupling and feedback between tectonics and surface processes during non-volcanic rifted margin formation. Journal of Geophysical Research: Solid Earth, 124, 12,323-12,347. https://doi.org/10.1029/2018JB017235

Thieulot, C., Steer, P., \& Huismans, R. (2014). Three-dimensional numerical simulations of crustal systems undergoing orogeny and subjected to surface processes. Geochemistry, Geophysics, Geosystems, 15, 4936-4957. https://doi.org/10.1002/2014GC005490

Townend, J., \& Zoback, M. (2004). Regional tectonic stress near the San Andreas fault in central and southern California. Geophysical Research Letters, 31, L15S11. https://doi.org/10.1029/2003GL018918

Vernant, P., Hivert, F., Chery, J., Steer, P., Cattin, R., \& Rigo, A. (2013). Erosion-induced isostatic rebound triggers extension in low convergent mountain ranges. Geology, 41, 467-470. https://doi.org/10.1130/G33942.1

Vidale, J. E., Agnew, D. C., Johnston, M. J., \& Oppenheimer, D. H. (1998). Absence of earthquake correlation with Earth tides: An indication of high preseismic fault stress rate. Journal of Geophysical Research, 103(B10), 24,567-24,572. https://doi.org/10.1029/98JB00594

Whipple, K. X. (2009). The influence of climate on the tectonic evolution of mountain belts. Nature Geoscience, 2(2), 97-104. https://doi. org/10.1038/ngeo413

Willett, S. D. (1999). Orogeny and orography: The effects of erosion on the structure of mountain belts. Journal of Geophysical Research, 104(B12), 28,957-28,981. https://doi.org/10.1029/1999JB900248

Yanites, B. J., Tucker, G. E., Mueller, K. J., \& Chen, Y.-G. (2010). How rivers react to large earthquakes: Evidence from central Taiwan. Geology, 38(7), 639-642. https://doi.org/10.1130/G30883.1 